\title{
Endogenous generation of reactive oxidants and electrophiles and their reactions with DNA and protein
}

\author{
Lawrence J. Marnett, James N. Riggins, and James D. West \\ A.B. Hancock Jr. Memorial Laboratory for Cancer Research, Department of Biochemistry, Vanderbilt University School of Medicine, \\ Vanderbilt Institute of Chemical Biology, Center in Molecular Toxicology, and Vanderbilt-Ingram Comprehensive Cancer Center, \\ Nashville, Tennessee, USA
}

J. Clin. Invest. 111:583-593 (2003). doi:10.1172/JCI200318022.

A constellation of reactive intermediates - electrophiles and free radicals - capable of damaging cellular constituents is generated during normal physiological or pathophysiological processes. The consequences of this damage include enhanced mutation rates, altered cell signaling, and events summarized in other articles in this Perspective series. In many cases, the initially generated reactive intermediates convert cellular constituents into second-generation reactive intermediates capable of inducing further damage. Cells have adapted to the existence of reactive intermediates by the evolution of defense mechanisms that either scavenge these intermediates or repair the damage they cause. High levels of damage can lead to cell death through apoptosis or necrosis. This article provides an overview of DNA and protein damage by endogenous electrophiles and oxidants and an introduction to the consequences of this damage.

\section{First-generation reactive intermediates}

Some reactive intermediates are produced as diffusible cofactors in normal metabolic pathways. For example, $S$-adenosylmethionine is a cofactor for many methylation reactions that are required in biosynthesis or in regulation of gene expression. The latter role requires its presence in the nucleus, where it also can react nonenzymatically with DNA bases to produce a variety of methylated derivatives. Some of these methylated DNA bases are highly mutagenic during DNA replication (see below).

\footnotetext{
Address correspondence to: Lawrence J. Marnett, Department of Biochemistry, Vanderbilt University School of Medicine, Nashville, Tennessee 37232-0146, USA.

Phone: (615) 343-7329; Fax: (615) 343-7534;

E-mail: marnett@toxicology.mc.vanderbilt.edu.

Conflict of interest: The authors have declared that no conflict of interest exists.

Nonstandard abbreviations used: superoxide anion $\left(\mathrm{O}_{2}^{-}\right)$; peroxynitrite $\left(\mathrm{ONOO}^{-}\right)$; peroxynitrous acid $(\mathrm{ONOOH})$; nitrosoperoxycarbonate $\left(\mathrm{ONO}_{2} \mathrm{CO}_{2}^{-}\right)$; nitroxyl anion $\left(\mathrm{NO}^{-}\right)$; 8-oxo-7,8-dihydrodeoxyguanosine (8-oxo-dG); 8-oxo-7,8dihydrodeoxyadenosine (8-oxo-dA); 5-hydroxydeoxycytidine (5-hydroxy-dC); 2'-deoxyadenosine (dA); 2'-deoxycytidine (dC); $2^{\prime}$-deoxyguanosine (dG); 2'-deoxythymidine (dT); malondialdehyde (MDA); 4-hydroxynonenal (4-HNE); pyrimidopurinone ( $\mathrm{M}_{1} \mathrm{dG}$ ); 8-hydroxypropanodeoxyguanosine (HO-PdG); methionine sulfoxide reductase A (MSRA).
}

Most reactive intermediates are produced as unavoidable consequences of our existence in an aerobic environment (Figure 1). Utilization of $\mathrm{O}_{2}$ for energy production puts us at risk because of the generation of reactive oxidants as products of $\mathrm{O}_{2}$ reduction. Mitochondria reduce $\mathrm{O}_{2}$ to water via cytochrome oxidase as the final step in respiratory electron transport. Although most of the electrons are successfully transferred down the chain, estimates suggest that up to $10 \%$ of the reducing equivalents from NADH leak to form superoxide anion $\left(\mathrm{O}_{2}^{-}\right)$and $\mathrm{H}_{2} \mathrm{O}_{2}$, which diffuse from the mitochondria (1). Macrophages and neutrophils reduce $\mathrm{O}_{2}$ to $\mathrm{O}_{2}{ }^{-}$via NADPH oxidase as part of the host defense system. Most of the $\mathrm{O}_{2}{ }^{-}$generated in inflammatory cells dismutates to form $\mathrm{H}_{2} \mathrm{O}_{2}$, which is a substrate for myeloperoxidase. $\mathrm{O}_{2}^{-}$is also generated in epithelial cells by the action of an NAPDH oxidase complex that is related to the oxidase complex in phagocytic cells but that has a much lower capacity for $\mathrm{O}_{2}{ }^{-}$generation (2). The low flux of oxidants in epithelial cells is believed to play a role in signaling.

In addition to serving as a source of $\mathrm{H}_{2} \mathrm{O}_{2}, \mathrm{O}_{2}{ }^{-}$can react with ferric ion or nitric oxide to generate more potent oxidants (Figure 1). Reduction of ferric ion produces ferrous ion, which can reduce $\mathrm{H}_{2} \mathrm{O}_{2}$ to hydroxide ion and hydroxyl radical. Hydroxyl radical has a redox potential of $2.8 \mathrm{~V}$, so it is an extremely strong oxidant capable of oxidizing virtually any molecule it encounters. Inflammatory cells generate copious amounts of $\mathrm{NO}$ and $\mathrm{O}_{2}^{-}$by the action of inducible $\mathrm{NO}$ synthase and NADPH oxidase, respectively. Both species are important components of the host defense system. Chronic activation of the inflammatory response can induce collateral damage in adjacent normal tissue, which contributes to a range of diseases (see below and other articles in this Perspective series).

Reaction of $\mathrm{O}_{2}^{-}$with $\mathrm{NO}$ produces peroxynitrite $\left(\mathrm{ONOO}^{-}\right)$. $\mathrm{ONOO}^{-}$and its protonated form, peroxynitrous acid $(\mathrm{ONOOH})$, react with cellular nucleophiles or oxidize hemeproteins to ferryl-oxo derivatives. Both $\mathrm{ONOOH}$ and ferryl-oxo complexes are strong oxidants. $\mathrm{ONOOH}$ is a direct oxidant and also undergoes homolysis to produce hydroxyl radical and $\mathrm{NO}_{2}{ }^{\bullet}(3,4)$. Approximately $25 \%$ of these radicals escape the solvent 

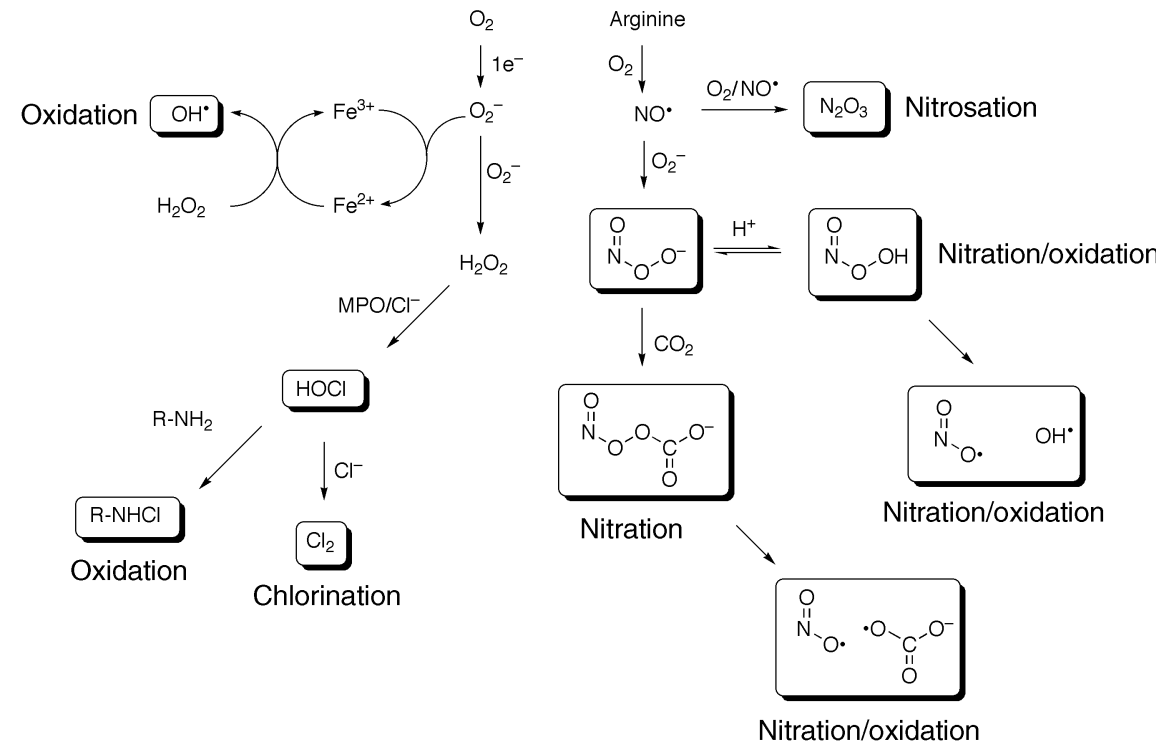

Figure 1

Reactive intermediates generated from superoxide and nitric oxide. MPO, myeloperoxidase.

\section{Second-generation reactive intermediates}

The oxidants generated from $\mathrm{O}_{2}$ reduction react with cellular components to produce a range of unstable oxidation products that can break down to diffusible electrophiles (Figure 2). For example, myeloperoxidase oxidizes $\alpha$-amino acids to aldehydes; of particular interest is the oxidation of threonine to acrolein (13). Polyunsaturated fatty acid residues in phospholipids are very sensitive to oxidation at the central carbon of their pentadienyl backbone. Oxidation of the pentadienyl functionality by oxidants such as hydroxyl radical and $\mathrm{ONOOH}$ leads to a complex series of reactions that generate a range of electrophilic derivatives

cage to react with cellular constituents (5). $\mathrm{ONOO}^{-}$ reacts with $\mathrm{CO}_{2}$ to form a carbonate adduct, nitrosoperoxycarbonate $\left(\mathrm{ONO}_{2} \mathrm{CO}_{2}^{-}\right)(6)$. The level of $\mathrm{CO}_{2}$ in most tissues is sufficient to trap all of the $\mathrm{ONOO}^{-}$released from inflammatory cells. The carbonate adduct is not as strong an oxidant as $\mathrm{ONOO}^{-}$ or $\mathrm{ONOOH}$, but it is an effective nitrating agent. The mechanism of nitration is believed to involve homolytic scission of $\mathrm{ONO}_{2} \mathrm{CO}_{2}^{-}$to carbonate radical, which can either oxidize $\mathrm{NO}_{2}{ }^{\bullet}$ to $\mathrm{NO}_{2}{ }^{+}$or oxidize DNA or protein to a derivative that then couples with $\mathrm{NO}_{2}{ }^{\bullet}$ to form a nitro derivative (e.g., tyrosine $\rightarrow$ tyrosyl radical; guanine $\rightarrow$ guanyl radical) (7).

In the presence of $\mathrm{O}_{2}, \mathrm{NO}$ generates a nitrosating agent that reacts with sulfhydryl groups to form $S$-nitroso derivatives (8). The chemistry of nitrosation is complex, but $\mathrm{N}_{2} \mathrm{O}_{3}$ appears to be the principal nitrosating agent produced. $S$-nitroso derivatives of proteins can demonstrate altered structural and functional properties depending upon their location in the protein. They also can transfer the nitroso group to other thiol-containing molecules (e.g., glutathione) or react with thiols to form mixed disulfides and release nitroxyl anion ( $\left.\mathrm{NO}^{-}\right)$.

$\mathrm{H}_{2} \mathrm{O}_{2}$ produced by inflammatory cells oxidizes myeloperoxidase to a higher oxidation state that has a redox potential in excess of $1 \mathrm{~V}$. This higher oxidation state (a ferryl-oxo complex) oxidizes $\mathrm{Cl}^{-}$to $\mathrm{HOCl}$, which is capable of oxidizing or chlorinating cellular macromolecules (Figure 1) (9). $\mathrm{HOCl}$ also reacts with amines to form chloramines or with $\mathrm{Cl}^{-}$to form $\mathrm{Cl}_{2}$ gas; the latter chlorinates DNA or protein (10). A similar cascade of reactions is triggered by bromoperoxidase in eosinophils (11). Myeloperoxidase also can oxidize nitrite to $\mathrm{NO}_{2}{ }^{\bullet}$, which can react with $\mathrm{NO}$ to form $\mathrm{N}_{2} \mathrm{O}_{3}$. This reaction may serve as an alternate pathway of protein nitrosation to the uncatalyzed reaction that produces $\mathrm{N}_{2} \mathrm{O}_{3}$ (which requires four NOs and $\mathrm{O}_{2}$ ) (12).
(Figure 2) (14). These include aldehydes and epoxides that are capable of reacting with protein or nucleic acid. $\alpha, \beta$-Unsaturated aldehydes are particularly important oxidation products, because they have two sites of reactivity, which leads to the formation of cyclic adducts or cross-links. Epoxyaldehydes display complex reactivity toward nucleophiles, including the transfer of a twocarbon unit to DNA bases (15). A series of dehydration and oxidation reactions leads to the formation of aldehydes and ketones from carbohydrates (Figure 2) (16). These compounds are capable of reacting with protein nucleophiles to form advanced glycation end products. So, when considering the consequences of the generation of cellular electrophiles and free radicals, one must realize that primary oxidants (e.g., $\left.\mathrm{HO}^{\circ}, \mathrm{ONOOH}\right) \mathrm{can}$ give rise to a range of secondary oxidants, free radicals, and electrophiles. Obviously, cells devote considerable energy to protecting themselves from the deleterious effects of this panoply of reactive intermediates, but consideration of these mechanisms is beyond the scope of this Perspective.

\section{Endogenous DNA damage}

Exposure to endogenous oxidants and electrophiles leads to increases in damage to cellular macromolecules, including DNA. This section catalogs the major types of DNA damage and how they affect replication. DNA damage can result from reactions with nucleic acid bases, deoxyribose residues, or the phosphodiester backbone. The majority of the literature focuses on damage to bases or degradation of deoxyribose residues (17). Unrepaired DNA lesions accumulate with time and can contribute to the development of age-related diseases.

The consequences of DNA damage have been analyzed in vitro through polymerase bypass and enzymatic repair experiments and in vivo using site-specific mutagenesis experiments in bacterial and mammalian cells $(18,19)$. 
From amino acid oxidation

$$
\mathrm{R}=\text { amino acid side chain } \quad \text { From threonine }
$$

From lipid peroxidation
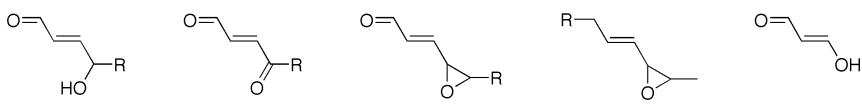

$\mathrm{R}=$ aliphatic side chains derived from fatty acids

From carbohydrate dehydration and oxidation
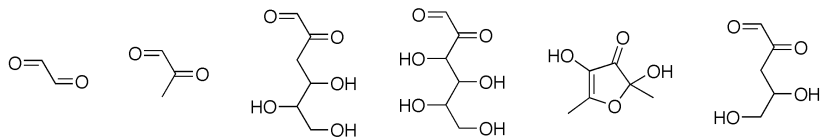

$=\mathrm{O}$

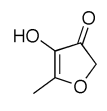

Figure 2

Reactive intermediates derived from amino acid, lipid, and carbohydrate oxidation.

Hydroxyl radical damage to pyrimidines is also mutagenic. 5-Hydroxydeoxycytidine (5-hydroxy-dC) induces $\mathrm{C} \rightarrow \mathrm{T}$ and $\mathrm{C} \rightarrow \mathrm{A}$ mutations in vitro and $\mathrm{C} \rightarrow \mathrm{T}$ transitions in vivo (29). 5 -Hydroxy-dC also deaminates to 5-hydroxy-deoxy-uracil, which codes as $\mathrm{T}$. This provides an additional mechanism for the induction of $\mathrm{C} \rightarrow \mathrm{T}$ transitions. Thymidine glycol causes $\mathrm{T} \rightarrow \mathrm{C}$ mutations in vivo $(30,31)$.

\section{Nitric oxide-mediated DNA damage}

As discussed earlier, nitric oxide can form $\mathrm{ONOOH}, \mathrm{ONO}_{2} \mathrm{CO}_{2}^{-}$, and $\mathrm{N}_{2} \mathrm{O}_{3}$. These reactive intermediates can damage DNA directly. $\mathrm{ONOOH}$ and $\mathrm{ONO}_{2} \mathrm{CO}_{2}^{-}$have

The extent of DNA damage has been evaluated by examination of tissues for adduct content (20). Adducts have been quantified at levels from as low as 1 in $10^{9}$ to as high as 1 in $10^{6}$ nucleotides, corresponding to approximately 3-3,000 adducts per cell. Though there is a great deal of interesting and controversial work defining adduct levels in various tissues, those data are beyond the scope of this Perspective. Due to space limitations, only a few illustrative examples of specific types of damage and their effects are discussed.

\section{Hydroxyl radical-mediated DNA damage}

Hydroxyl radical can add to double bonds of DNA bases or abstract hydrogen atoms from either methyl groups or deoxyribose residues (21) (Figure 3). Hydroxyl radical reacts with purines by adding to the 7,8 double bond to generate the 8-oxo-7,8-dihydrodeoxyguanosine (8-oxo-dG) that is more abundant than 8-oxo-7,8-dihydrodeoxyadenosine (8-oxo-dA) (22). Hydroxyl radical also adds to the 5,6 double bond of pyrimidines to produce pyrimidine glycols (23). Alternatively, hydrogen abstraction from the 5-methyl group of thymine can produce a carbon-centered radical that reacts with molecular oxygen to form a hydroperoxide; this hydroperoxide is reduced to hydroxymethyl-dU. Hydrogen-atom abstraction from deoxyribose can lead to single-strand breaks concomitant with the formation of base propenals (21). The latter are substituted enals and can react with nucleophilic sites elsewhere on DNA (see below).

8-Oxo-dG induces transversions to $\mathrm{T}$ or $\mathrm{C}$ in both in vitro replication experiments and in vivo mutagenesis experiments (Table 1$)(24,25) . A \rightarrow C$ mutations have been observed as a result of in vitro replication of 8-oxo-dA (26). 8-Oxo-dG and 8-oxo-dA are known to undergo imidazole ring-opening to formamidopyrimidine (FAPy) adducts, which are minor, alkali-labile products of purine oxidation (27). Both 8-oxo-dG and FAPy adducts are repaired by glycosylases in prokaryotic and eukaryotic systems (28). been shown to form nitrated nucleosides, the most abundant of which occur on dG (e.g., 8-nitro-dG) (32). 8-Nitro$\mathrm{dG}$ is an unstable adduct, and its glycosidic bond readily hydrolyzes to form an abasic site. Strand cleavage, seen when cells are exposed cells to $\mathrm{ONOOH}$, is presumed to arise from 8-nitro-dG depurination (32). Alternatively, 8-nitro-dG may decompose by reaction with another equivalent of $\mathrm{ONOOH}$ to form 8-oxo-dG (33). 8-Oxo-dG itself can be oxidized by $\mathrm{ONOOH}$ to form degradation products; 3a-hydroxy-5-imino-3,3a,4,5-tetrahydro- $1 H$ imidazo[4,5-d] imidazol-2-one is an intermediate formed from 8-oxo-dG at low ONOOH concentrations (32).

$\mathrm{N}_{2} \mathrm{O}_{3}$ reacts with the exocyclic amines of $2^{\prime}$-deoxyadenosine (dA), 2'-deoxycytidine (dC), and 2'-deoxyguanosine $(\mathrm{dG})$ to produce nitroso and then diazo intermediates that are hydrolyzed to hypoxanthine, uracil, and xanthine; these are all potentially mispairing lesions. Human cells treated with NO exhibit both $\mathrm{G} \rightarrow \mathrm{A}$ transitions and $\mathrm{G} \rightarrow \mathrm{T}$ transversions, presumably from uracil and xanthine, respectively $(32,34)$.

\section{Table 1}

Mutagenic consequences of replication of endogenous DNA adducts

Damage type

Mutations

Ref.

Adenine

8-Oxo-dA

Etheno-dA

$A \rightarrow C$

$A \rightarrow G$

21

Cytosine

5-Methyl-dC

Etheno-dC

$\mathrm{C} \rightarrow \mathrm{T}$

$\mathrm{C} \rightarrow \mathrm{A}, \mathrm{C} \rightarrow \mathrm{T}$

48

Guanine

$\mathrm{O}^{6}$-methyl-dG

$\mathrm{M}_{1} \mathrm{dG}$

8-Bromo-dG

8-Oxo-dG

$1, N^{2}$-etheno-dG

$\mathrm{G} \rightarrow \mathrm{T}$

$\mathrm{G} \rightarrow \mathrm{T}, \mathrm{G} \rightarrow \mathrm{A}$

$\mathrm{G} \rightarrow \mathrm{T}$

$\mathrm{G} \rightarrow \mathrm{A}$

$\mathrm{G} \rightarrow \mathrm{A}, \mathrm{G} \rightarrow \mathrm{T}$

$\mathrm{T} \rightarrow \mathrm{C}$

30 
Hydroxyl radical
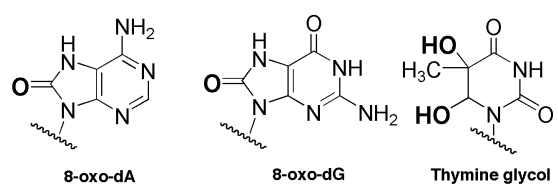

8-oxo-dA

8-oxo-dG

Thymine glyco

5-hydroxy-dC

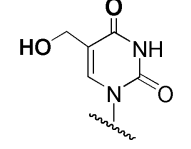

5-hydroxymethyl-dU
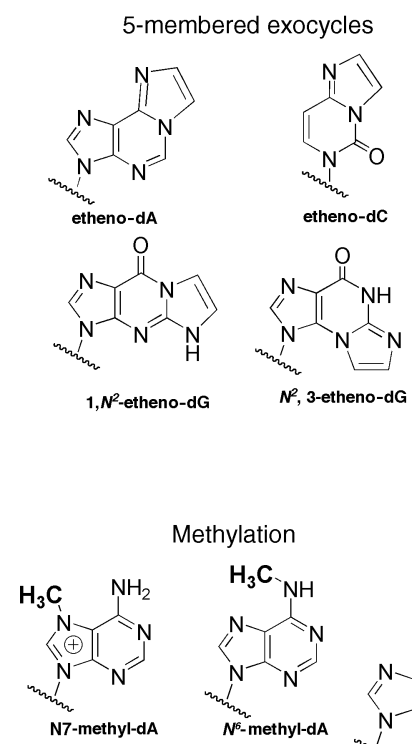

Methylation
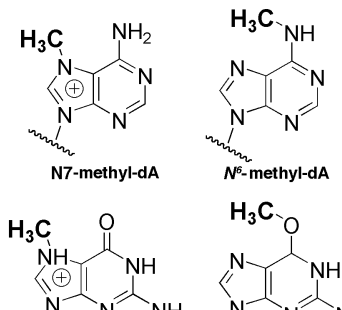

N7-methyl-dG

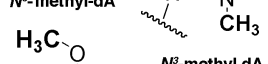

$\mathrm{H}_{3} \mathrm{C}_{\mathrm{O}} \quad \mathrm{N}^{3}$-methyl dA<smiles></smiles>

Nitric oxide

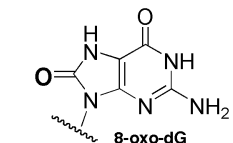<smiles>CC(C)N1c2nc(N)[nH]c(=O)c2NC1[N+](=O)[O-]</smiles><smiles>CC12CC3=NC(=O)N1C(N2)C(=N)N3</smiles><smiles>CCn1cnc2c(=O)[nH]c(Nc3nc4c(ncn4CC)c(=O)[nH]3)nc21</smiles>

3a-hydroxy-5-imino-3,3a,4,5-tetrahydro-

Enals
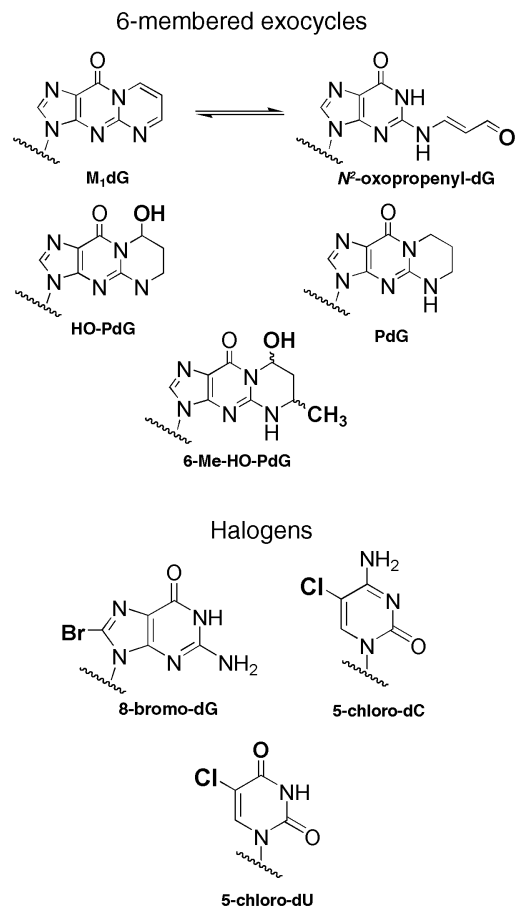

Figure 3

Endogenous products of DNA damage.

Furthermore, adjacent guanines can cross-link by an $\mathrm{N}_{2} \mathrm{O}_{3}$-mediated conversion of the amine on one guanine to a diazonium ion, followed by the attack of the exocyclic amine of the neighboring dG (32). $\mathrm{N}_{2} \mathrm{O}_{3}$ also has been shown to induce single-strand breaks on naked DNA and in intact cells.

\section{Enal and exocyclic adducts}

Enals can react at the exocyclic amino groups of $d G$, $\mathrm{dA}$, and $\mathrm{dC}$ to form various alkylated products. Some common enals that cause DNA damage are malondialdehyde (MDA), acrolein, crotonaldehyde, and 4-hydroxynonenal (4-HNE). Enals are bifunctional electrophiles that present two reactive sites to DNA. The most common adducts arising from enals are exocyclic adducts such as etheno adducts from dA, dG, and $\mathrm{dC}$; a pyrimidopurinone $\left(\mathrm{M}_{1} \mathrm{dG}\right)$ adduct from $\mathrm{dG}$; and 8-hydroxypropanodeoxyguanosine (HO-PdG) adducts from dG. Etheno adducts also arise from reac- tion of exogenous sources such as vinyl chloride, and substituted etheno adducts originate from the 4-HNE derivative 4-oxo-nonenal $(35,36)$.

Etheno adducts are mispairing and mutagenic in bacterial and mammalian cells, although significant differences in mutagenicity have been described in prokaryotes and eukaryotes with regard to etheno-dA (35). Bacterial and mammalian cells have evolved base excision repair pathways to deal with etheno adducts. $1, N^{6}$-etheno-dA and, to a lesser extent, $N^{2}, 3$-etheno-dG are excised by $N$-methylpurine-glycosylases, whereas $3, N^{4}$-etheno-dC has been shown to be repaired by a mismatch-specific thymine-DNA glycosylase (37-39).

The $\mathrm{M}_{1} \mathrm{dG}$ adduct arises by reaction of MDA with $\mathrm{dG}$ residues (40). When positioned in duplex DNA opposite $\mathrm{dC}, \mathrm{M}_{1} \mathrm{dG}$ undergoes hydrolytic ring-opening to $N^{2}$-oxopropenyl-dG (41). Both the ring-closed and the ring-opened adducts are mutagenic in bacteria $(\mathrm{G} \rightarrow \mathrm{A}$ and $\mathrm{G} \rightarrow \mathrm{T}$ in both cell types) (42). The mutagenic fre- 
quency induced by the ring-opened form is lower than that observed for the ring-closed form.

Crotonaldehyde is mutagenic and forms diastereomeric six-membered ring adducts (6-methyl-HOPdG) in vitro (43). HO-PdG, the structurally related adduct derived from acrolein, is mutagenic in vitro and in vivo $(44,45)$. The unsubstituted propano-dG $(\mathrm{PdG})$ adduct is mutagenic in vitro and in vivo and causes frameshift mutations (though PdG is not physiologically relevant) $(42,46)$. Some exocyclic adducts (e.g., $\mathrm{M}_{1} \mathrm{dG}$ and HO-PdG) are themselves electrophilic and may react with nucleophilic sites in small molecules, DNA, or protein, thereby forming cross-links (6).

\section{DNA methylation}

DNA methylation occurs through the nonenzymatic reaction of bases with $S$-adenosylmethionine and various exogenous methylating agents. The most common sites of damage are on 2'-deoxythymidine (dT), forming $O^{4}$-methyl-dT; on $\mathrm{dG}$, forming $O^{6}$-methyl-dG and N7-methyl-dG; and on dA, forming N3-methyl-dA, $N^{6}$-methyl-dA, and N7-methyl-dA (47). Enzymatic methylation with $S$-adenosylmethionine on cytosine plays a role in mammalian gene regulation and imprinting, which can lead to functional inactivation of genes.

Methylated bases are mispaired in vitro and in vivo and can interfere with the binding of DNA enzymes and regulatory elements. Mutagenic events in Escherichia coli and mammalian cells reveal that $O^{6}$-methyl-dG mispairs with thymidine to generate $\mathrm{G} \rightarrow \mathrm{A}$ transitions (47). $\mathrm{O}^{4}$-methyl-dT causes $\mathrm{T} \rightarrow \mathrm{C}$ transitions, whereas N3-methyl$\mathrm{dA}$ and $N^{6}$-methyl-dA promote $\mathrm{A} \rightarrow \mathrm{G}$ transitions and abasic site formation (47). Methylation on N7 of purines causes destabilization of the glycosidic bond, and subsequent depurination to an abasic site. A number of glycosylases from prokaryotes and eukaryotes have been isolated that remove alkyl adenine damage. $O^{6}$-methyl-dG and alkyl-substituted adenine also have been directly implicated in methylation sensitivity in a variety of cell types (47). Strains with compromised or deleted $O^{6}$-methyl-dG repair (such as methylguanine methyltransferase) or alkyl adenine repair (encoded by AlkA in E. coli or by aag in humans) demonstrate higher levels of mutation and cell death when exposed to methylating agents (48).

\section{Halogens}

The generation of $\mathrm{HOCl}$ provides a pathway for the halogenation of DNA bases. 5-Chloro-dC has been observed as the major product of reaction of $\mathrm{HOCl}$ with DNA and has been detected in human tissues (49). Similarly,

Figure 4 eosinophil peroxidases produce hypobromous acid ( $\mathrm{HOBr})$, which generates 5-bromo-dC and the deamination product 5-bromo-dU (11). Halogenation at the 5 position of pyrimidines may lead to mispairing. Chlorinated products, most notably 8-chloro-purines, have been isolated (50). These lesions are mispairing and cause transitions and transversions (50).

In addition to causing replication errors that lead to genetic disease, DNA damage triggers signaling cascades that slow cell cycle progression or lead to apoptosis. For example, treatment of cultured colon cancer cells with concentrations of MDA that lead to levels of $\mathrm{M}_{1} \mathrm{dG}$ of approximately 1 in $10^{7}$ nucleotides induces cell cycle arrest at the G1/S and G2/M transitions (51). The sensors of DNA damage and the signaling pathways that lead to cell cycle arrest and apoptosis are areas of very active investigation.

\section{Amino acid and protein damage}

Protein damage that accumulates during oxidative stress is unquestionably more diverse than the spectrum of intermediates that causes it. Modification of polypeptides by reactive species can occur on the peptide backbone, various nucleophilic side chains, and redox-sensitive side chains (Figure 4). For many of the reactive species discussed earlier, the modifications that they carry out on proteins have been characterized, and several of their molecular targets are known.

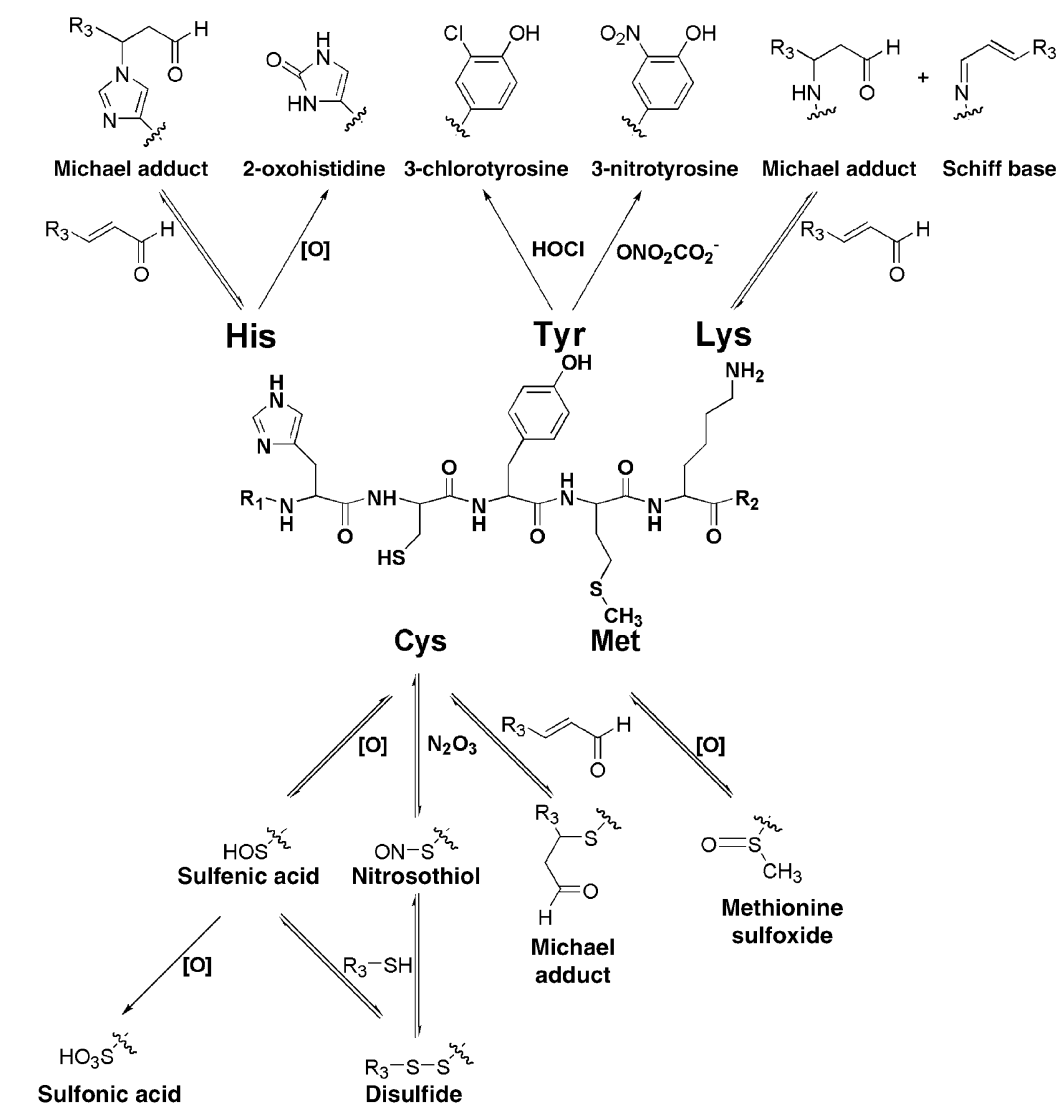

Endogenous damage to amino acid side chains. 
In many cases, the chemistry associated with protein damage is dynamic and reversible, although several types of protein adducts accumulate during aging and/or age-related diseases.

\section{Damage to peptide backbones}

Free radicals produced during oxidative stress can damage the peptide backbone, resulting in the generation of protein carbonyls. The process is initiated by hydrogen abstraction from the $\alpha$-carbon in a peptide chain. If two protein radicals are in close proximity, they may cross-link with one another by radical coupling (52). Alternatively, $\mathrm{O}_{2}$ can attack the $\alpha$-carboncentered radical to form peroxide intermediates, leading to rearrangement and subsequent cleavage of the peptide bond to form carbonyl-containing peptides (52). Protein carbonyls also may be generated by the oxidation of several amino acid side chains (e.g., Lys, Arg, Pro) and by the formation of Michael adducts between nucleophilic residues and $\alpha, \beta$-unsaturated aldehydes (see below) (53). Carbonyl content can be analyzed by reaction of 2,4-dinitrophenylhydrazine with proteins to form the corresponding hydrazone. As a marker of oxidative damage to proteins, protein carbonyls have been shown to accumulate during aging and age-related disease in a variety of organisms (53). Levels of protein carbonyls are, therefore, a potentially useful indicator of intracellular redox status.

\section{Modification of side chains by intracellular oxidants and radicals}

Intracellular oxidants and radicals carry out numerous modifications on the side chains of amino acid residues in polypeptides. Although most amino acids can be modified by various endogenous oxidants, residues commonly modified by $\mathrm{HO}^{\circ}, \mathrm{O}_{2}^{-}, \mathrm{HOCl}, \mathrm{ONOOH}$, and $\mathrm{ONO}_{2} \mathrm{CO}_{2}^{-}$include cysteine, tyrosine, and methionine. Reversible oxidation of the sulfhydryl group on cysteine converts it to cysteine sulfenic acid, which can react with thiols or undergo further irreversible oxidation to a sulfinic acid and a sulfonic acid (Figure 4) (54). Thiols with particularly low $\mathrm{p} K_{\mathrm{a}}$ 's are most susceptible to oxidation. Sulfenic acids in proteins can react with glutathione or other sulfhydryl-containing molecules to form disulfide bonds (54). In the case of glutathione, the formation of the disulfide bond is termed glutathionylation. Disulfide bonds accumulate under oxidizing conditions, but they can be readily reduced to free sulfhydryl groups by the enzyme thioredoxin or by reducing agents (55).

Recent discoveries in the biology of nitrosating agents, such as $S$-nitrosoglutathione (GSNO), have revealed that several proteins are particularly susceptible to $S$-nitrosation at specific cysteine residues. In searching for consensus nitrosation sites, it has been suggested that there are both hydrophobic and acidbase motifs in target proteins adjacent to the site of their modification (56). GSNO, a commonly used exogenous nitrosating agent, has been detected in vivo at micromolar concentrations in brain tissue and can directly transfer $\mathrm{NO}$ equivalents to target protein thiols (8). Additionally, other mechanisms of $S$-nitrosation of nucleophilic cysteines (e.g., by $\mathrm{N}_{2} \mathrm{O}_{3}$ ) are plausible (8). $S$-nitrosothiols in proteins can react with free sulfhydryl groups to create disulfide bonds and can be reduced by various reductants (8). Although the chemical pathways through which nitric oxide forms $S$-nitrosocysteine are complex, experiments using induced expression of NO synthase isoforms and neuronal NO synthase knockout cells have established that NO production increases levels of overall protein $S$-nitrosation $(57,58)$. $S$-nitrosation of proteins is potentially a key method that cells use to mediate inflammatory responses and other NO-regulated processes.

Methionine residues in proteins are highly susceptible to oxidation by various reactive intermediates. Upon oxidation, methionine is converted to methionine sulfoxide and can be further oxidized to methionine sulfone (59). Oxidation of methionine residues in proteins can be reversed by methionine sulfoxide reductase A (MSRA), an NADH-dependent enzyme that reduces methionine$R$-sulfoxide to methionine (59), or by selenoprotein $\mathrm{R}$, an enzyme that acts on the methionine-S-sulfoxide stereoisomer (60). It has been proposed that methionine residues in proteins serve protective roles by preventing oxidative damage at other residues, since methionine oxidation is enzymatically reversible (59). In accordance with this hypothesis, mice lacking the $M s r A$ gene have decreased life spans, behavioral abnormalities, and increased protein carbonyl levels (61). A separate study using a transgenic MSRA Drosophila model supports these observations by demonstrating that transgenic flies that overexpress MSRA live longer, more active lives when compared with wild-type littermates (62).

Oxidants generated during stress can modify the aromatic residues phenylalanine and tyrosine. Phenylalanine is sensitive to oxidation by $\mathrm{HO}^{\circ}$ and transition metals, which cause its conversion to $o$ - and $m$-tyrosine. Tyrosine residues can be modified by several oxidants, including $\mathrm{HOCl}, \mathrm{ONOOH}$, and $\mathrm{ONO}_{2} \mathrm{CO}_{2}^{-}$(63). A variety of oxidative modifications can occur to tyrosine side chains in proteins, including formation of $o, o^{\prime}$-dityrosine, 3,4-dihydroxyphenylalanine, 3-nitrotyrosine, and 3-chlorotyrosine. These modifications are likely irreversible, so inactivation of various proteins in this manner could have lasting detrimental effects. Recent reports have documented that 3-nitrotyrosine and 3-chlorotyrosine can be generated ex vivo during sample processing, illustrating the limitations of some quantitative methods that do not use isotopically labeled internal standards that can distinguish in vivo from ex vivo generation (e.g., immunochemical, spectroscopic, and electrochemical detection). This underscores the importance of developing robust analytical methods and validating them in in vivo settings. Indeed, some advances in the mass spectrometric quantification of tyrosine modification have been described (64-66). Application of these methods has demonstrated increases in oxidative damage to aromatic amino acid residues in atherosclerosis and other degenerative dis- 
eases, supporting the hypothesis that aromatic amino acid damage contributes to the development and/or progression of various age-related diseases $(67,68)$.

\section{Modification of proteins by aldehydic intermediates}

Modification of amino acids by $\alpha, \beta$-unsaturated aldehydes commonly occurs on the nucleophilic residues cysteine, histidine, and lysine (Figure 4) $(16,69)$. The chemistry that shorter $\alpha, \beta$-unsaturated aldehydes undergo when reacting with proteins is slightly different from that of the reactions depicted in Figure 4. For instance, two molecules of acrolein react with the $\varepsilon$-amino group of lysine to form predominantly a cyclic 3-formyl-3,4-dehydropiperidino adduct (16). MDA mainly reacts with lysine residues by Michael addition, but other forms of multimerized MDA have been found to react with lysine as well (16). Michael adducts between 4-hydroxy-2-alkenals and cysteine, histidine, and lysine are formed as depicted, as well as Schiff base adducts that form only following reaction with the amino group on lysine residues $(16,69)$. The products of 4-hydroxy-2-alkenals can be converted to more stable structures, including cyclic hemiacetals, pyrroles, and various other structures $(16,69)$. Increased levels of acrolein and 4-HNE protein adducts, abundant products of lipid peroxidation, are found in cardiovascular disease and neurodegenerative diseases $(16,69)$.

\section{Protein targets of reactive species}

Endogenous oxidants and electrophiles modify a host of proteins that run the gamut of biological functions (Table 2). For most protein targets, there is a remarkable specificity in the type and location of the residue(s) modified. An exhaustive description of these targets, the effect that is mediated, and the modifying agent that carries out the damage is not possible due to space limitations. For more information, the reader is referred to other articles that deal with protein targets of individual modifying agents $(59,70,71)$. A survey of common protein targets is listed in Table 2 and is expounded below. Where possible, the modifications are described, and the biological consequences are discussed.

\section{Damage to structural proteins}

Cell structure is maintained through a variety of cytoskeletal components including tubulin and filamentous proteins. Due to their abundance in specific cell types, these proteins are common targets of a variety of reactive species. Although the consequences of these modifications are still unclear, functional assays have been developed for some damaging agents. Tubulin isoforms are modified in vitro and in vivo by a number of intermediates, including nitrosating agents and 4-HNE (57, 72). 4-HNE forms Michael adducts with tubulin isoforms and disrupts microtubule assembly in neuroblastoma cells, blocking neurite outgrowth

Table 2

Common protein targets of reactive endogenous intermediates

\begin{tabular}{|c|c|c|c|c|}
\hline Protein target & Residue modified & Modifying agents & Biological consequences & Ref. \\
\hline \multicolumn{5}{|l|}{ Enzymes } \\
\hline Caspases & Catalytic cysteine & $\mathrm{HO}^{\bullet}$, nitrosating agents & $\begin{array}{l}\text { Glutathionylation, inactivation, } \\
\text { reduced death by apoptosis, necrosis (?) }\end{array}$ & $80-83,95,96$ \\
\hline $\begin{array}{l}\text { Protein tyrosine } \\
\text { phosphatases }\end{array}$ & $\begin{array}{l}\text { Catalytic cysteine, } \\
\text { active-site tyrosine (?) }\end{array}$ & $\begin{array}{l}\mathrm{HO}^{*}, \mathrm{O}_{2}^{-}, \text {nitrosating } \\
\text { agents, } \mathrm{ONOOH}\end{array}$ & $\begin{array}{l}\text { Glutathionylation, inactivation, } \\
\text { accumulation of phosphotyrosine, } \\
\text { prolonged activation of MAPKs (?) }\end{array}$ & $84-90,97-100$ \\
\hline IKB kinase & Active-site cysteine (?) & 4-HNE, $\mathrm{HO}^{\bullet}$ & Inactivation of NF- $\kappa \mathrm{B}$ signaling & 101,102 \\
\hline Tyrosine hydroxylase & Active-site tyrosine(s) & ONOOH & $\begin{array}{l}\text { Inhibition of dopamine synthesis, possible } \\
\text { role in progression of Parkinson disease }\end{array}$ & 77-79 \\
\hline $\begin{array}{l}\text { Mn-superoxide } \\
\text { dismutase }\end{array}$ & Active-site tyrosine & $\mathrm{ONOOH}$ & $\begin{array}{l}\text { Prevention of } \mathrm{O}_{2}^{-} \text {detoxification, } \\
\text { potential role in transplant rejection }\end{array}$ & $74-76$ \\
\hline$H$-ras (p21) & $\begin{array}{l}\text { Cysteine near } \\
\text { GTP-binding site }\end{array}$ & $\mathrm{NO}, \mathrm{HO}^{\bullet}$ & $\begin{array}{l}\text { Destabilization of GDP binding, } \\
\text { activation of signaling downstream of Ras }\end{array}$ & $103-107$ \\
\hline GAPDH & Catalytic cysteine (?) & $\begin{array}{c}\text { 4- } \mathrm{HNE}, \mathrm{HO}^{*}, \mathrm{O}_{2}^{-} \\
\text {nitrosating agents, } \mathrm{ONOOH}\end{array}$ & $\begin{array}{l}\text { Glutathionylation, inactivation, } \\
\text { modification by NADH }\end{array}$ & $57,108-115$ \\
\hline \multicolumn{5}{|c|}{ Structural and membrane proteins } \\
\hline Tubulin & Cysteine residue(s) & $\begin{array}{l}\text { 4-HNE, nitrosating agents, } \\
\text { ONOOH }\end{array}$ & Disruption of microtubule networks & $57,72,116$ \\
\hline $\begin{array}{l}\text { Neurofilament } \\
\text { heavy subunit }\end{array}$ & $\begin{array}{l}\text { Lysine and cysteine } \\
\text { residues }\end{array}$ & 4-HNE, nitrosating agents & Unknown & 57,73 \\
\hline $\begin{array}{l}\mathrm{N} \text {-methyl-D-aspartate } \\
\text { receptor channel }\end{array}$ & $\begin{array}{l}\text { Extracellular cysteine } \\
\text { residue }\end{array}$ & Nitrosating agents & Inactivation, reduced $\mathrm{Ca}^{2+}$ influx & $117-120$ \\
\hline \multicolumn{5}{|l|}{ Transcription factors } \\
\hline$N F-\kappa B$ & $\begin{array}{c}\text { Cysteine in DNA-binding } \\
\text { domain }\end{array}$ & $\mathrm{HO}^{\bullet}$, nitrosating agents & $\begin{array}{l}\text { Glutathionylation, inhibition } \\
\text { of NF-KB transcriptional activity }\end{array}$ & $121-126$ \\
\hline AP-1 & $\begin{array}{c}\text { Cysteine in DNA-binding } \\
\text { domain }\end{array}$ & Various oxidants, $\mathrm{NO}$ & Glutathionylation, inhibition of DNA binding & $127-130$ \\
\hline OxyR & Cysteine residues & $\mathrm{HO}^{\bullet}$, nitrosating agents & $\begin{array}{l}\text { Glutathionylation, transcriptional activation } \\
\text { of OxyR-responsive genes, clearance } \\
\text { of oxidants and other reactive species }\end{array}$ & $91,92,131-134$ \\
\hline
\end{tabular}


(72). Additionally, neurofilament heavy chains have been identified as targets of nitrosating agents and 4 -HNE $(57,73)$. The mechanistic features and the effect(s) seen with modification of neurofilaments by these and other agents remain to be elucidated.

\section{Damage to metabolic and detoxification enzymes}

Disruption of housekeeping enzymatic activities can occur in response to various endogenously produced electrophiles and radicals and may serve to potentiate stress responses. For instance, $\mathrm{Mn}$-superoxide dismutase has been shown to be inactivated in rejected kidney transplants (74). Accumulation of 3-nitrotyrosine, an adduct of $\mathrm{ONO}_{2} \mathrm{CO}_{2}^{-}$, is observed on $\mathrm{Mn}$-superoxide dismutase in the same patients (74), presumably on a single activesite tyrosine $(75,76)$. Upon inactivation of this key detoxifying enzyme, superoxide and $\mathrm{ONOO}^{-}$can accumulate and potentially trigger more protein and DNA damage. Tyrosine hydroxylase is the rate-limiting enzyme in the biosynthesis of L-dopamine, an essential chemical for the proper function of dopaminergic neurons. L-dopamine levels are substantially reduced in Parkinson disease patients. It has recently been shown that tyrosine hydroxylase isolated from the brains of mice that are models for Parkinson disease contains 3-nitrotyrosine adducts and exhibits reduced enzymatic activity (77). Upon in vitro modification of tyrosine hydroxylase with $\mathrm{ONOOH}$, several active-site tyrosine residues are damaged $(78,79)$. These data support the hypothesis that tyrosine hydroxylase is a critical target for oxidative inactivation in Parkinson disease.

\section{Damage to proteins involved in cell signaling and gene expression}

Numerous studies have revealed the importance of reactive species in altering cell signaling pathways that are critical for cell growth, differentiation, and/or survival. Targets of reactive intermediates include apoptotic caspases, protein tyrosine phosphatases, certain kinases, and the transcription factors AP-1, NF- $\mathrm{KB}$, and OxyR. Of these, perhaps the most extensive work has been performed on modification of protein tyrosine phosphatases, caspases, and OxyR.

Caspases, the cysteine protease executioners of the apoptotic response, can be modified by oxygen radicals and various nitrosating agents. These enzymes catalyze the proteolysis of proteins necessary for cell survival, using a nucleophilic cysteine residue in the active site to stimulate cleavage of target proteins at consensus aspartate residues. Several studies have shown that caspase-3, upon modification by radicals and nitrosating agents, is inactivated (80-82); presumably the inactivating modification of caspase- 3 occurs on its catalytic cysteine residues (80-82). It has recently been demonstrated that $S$-nitrosated caspase- 3 molecules are predominantly localized to the mitochondria (83), suggesting that this regulatory modification may prevent activation of caspase- 3 in specific cellular organelles. The modification of caspase- 3 by various agents represents a potential method for regulating its activity, thereby preventing apoptosis.
A large family of protein tyrosine phosphatases exists to modulate signaling by growth factors and other agonists. All members of the protein tyrosine phosphatase family function via a common catalytic mechanism that utilizes a single cysteine residue; these active-site cysteines have $\mathrm{p} K_{\mathrm{a}}$ 's of approximately 5.5. Because of their low $\mathrm{p} K_{\mathrm{a}}$ 's, the catalytic cysteines are susceptible to inactivation by oxygen radicals, $\mathrm{ONOOH}$, and nitrosating agents, being converted to a sulfenic acid, a sulfonic acid, $S$-nitrosocysteine, or a glutathionylated cystine (84-90). In cells subjected to oxidative stress, inactivation of protein tyrosine phosphatases is associated with an accumulation of phosphotyrosine and the potential for prolonged activation of specific stress-responsive and/or mitogenic signaling pathways (87).

One prototypical transcription factor that is regulated by oxidation and $S$-nitrosation is the bacterial protein OxyR. This homotetrameric protein undergoes a conformational change and becomes activated when critical cysteine residues are nitrosated or oxidized (91). Subsequently, OxyR activates transcription of several bacterial genes that protect against and/or repair oxidative damage. Various modifications of OxyR (i.e., $S$-nitrosation, sulfenic acid formation, and glutathionylation) influence its DNA-binding and transcriptional activation properties differently, suggesting that these modifications are responsible for varied biological responses (92). Knowledge gained from the study of OxyR may be useful in studying the effects of oxidants on oxidant-sensitive eukaryotic transcription factors, such as AP-1 and NF- $\mathrm{\kappa B}$.

\section{Proteomic approaches for identifying protein targets of reactive species}

Proteome-wide screening for modified proteins promises to be an exciting area of research in the immediate future. High-throughput methods have recently been developed for examining global protein $S$-nitrosation, glutathionylation, and tyrosine nitration $(57,93,94)$. Although most current methods use the power of mass spectrometry for identification of proteins, the approaches taken to enrich for and isolate modified proteins differ. For example, an elegant approach to the isolation of $S$-nitrosated proteins was recently reported (57). Free thiol groups were reacted with methyl methanethiosulfonate, and then $S$-NO groups were reduced to free thiols by treatment with ascorbate. Subsequently, using streptavidin agarose beads, the newly released protein thiols were converted to biotin conjugates to enrich for proteins. Peptides from isolated proteins were identified using matrix-assisted laser desorption ionization mass spectrometry. Approximately 15-20 proteins were identified as targets of nitrosating agents. The methodology was validated by confirmation that many targets of exogenous nitrosating agents are in vivo targets, as revealed by the lack of labeling in brain lysates from mice deficient in neuronal NO synthase.

In another method, glutathionylated proteins were identified by incubation of cells with radiolabeled cysteine in the absence of protein synthesis, exposure of $\mathrm{T}$ 
lymphocytes to agents that create an oxidative intracellular environment, isolation and detection of radiolabeled (i.e., glutathionylated) proteins, and identification of radiolabeled peptides by mass spectrometry (93). This study reveals that numerous proteins are targets for redox-dependent modification. Several of the enzymes identified were inactivated in in vitro assays, implying that glutathionylation of proteins upon alteration of cellular redox status is a potential mechanism for regulating the activity of many targets.

A similar methodology has been developed for identifying tyrosine damage by $\mathrm{ONO}_{2} \mathrm{CO}_{2}{ }^{-}$following exposure of cells or animals to inflammatory stimuli (94). This approach uses detection of proteins containing 3-nitrotyrosine residues by Western blotting following two-dimensional electrophoresis. Proteins from A549 cells, rat liver, or rat lung were partially transferred to membranes, and nitrated proteins were identified by Western blotting. The spots of the gel comigrating with those staining positive by Western blot were extracted and identified by mass spectrometry. Approximately 40 proteins were identified in this study as targets of $\mathrm{ONO}_{2} \mathrm{CO}_{2}{ }^{-}$, although the biological consequences of nitration in most cases remain to be determined.

\section{Concluding thoughts}

Research in the past twenty years has heightened our awareness of the importance of endogenous metabolic processes in cellular dysfunction, mutagenesis, and death. Much of this work has been descriptive, because the tools needed to ask discrete molecular questions were not available. However, there has been a dramatic and recent transformation in our ability to conduct qualitative and quantitative analysis of nucleic acid and protein modification. Thus, it is reasonable to assume that the next few years will witness a more precise definition of the events that lead from chemical modification to altered cellular function and/or heritable genetic change. This application of the tools of chemistry to biology will provide a strong experimental basis for the development of new diagnostic, therapeutic, and preventive strategies.

\section{Acknowledgments}

We are grateful to Celeste Riley for helpful editorial suggestions. Work in the Marnett laboratory is supported by research grants from the NIH (CA-77839, CA-87819, CA-89450, and GM-15431) and from the National Foundation for Cancer Research.

1. Floyd, R.A., West, M., and Hensley, K. 2001. Oxidative biochemical markers; clues to understanding aging in long-lived species. Exp. Gerontol. 36:619-640.

2. Babior, B.M. 2000. The NADPH oxidase of endothelial cells. IUBMB Life. 50:267-269.

3. Koppenol, W.H., Moreno, J.J., Pryor, W.A., Ischiropoulos, H., and Beckman, J.S. 1992. Peroxynitrite: a cloaked oxidant from superoxide and nitric oxide. Chem. Res. Toxicol. 5:834-842.

4. Hodges, G.R., and Ingold, K.U. 1999. Cage escape of geminate radical pairs can produce peroxynitrate from peroxynitrite under a wide variety of experimental conditions. J. Am. Chem. Soc. 121:10695-10701.

5. Goldstein, S., Czapski, G., Lind, J., and Merenyi, G. 2001. Gibbs energy of formation of peroxynitrite: order restored. Chem. Res. Toxicol. 14:657-660.
6. Lymar, S.V., and Hurst, J.K. 1995. Rapid reaction between peroxonitrite ion and carbon dioxide: implications for biological activity. J. Am. Chem. Soc. 117:8867-8868.

7. Squadrito, G.L., and Pryor, W.A. 2002. Mapping the reaction of peroxynitrite with $\mathrm{CO}_{2}$ : energetics, reactive species, and biological implications. Chem. Res. Toxicol. 15:885-895.

8. Hogg, N. 2002. The biochemistry and physiology of S-nitrosothiols. Annu. Rev. Pharmacol. Toxicol. 42:585-600.

9. Winterbourn, C.C., Vissers, M.C., and Kettle, A.J. 2000. Myeloperoxidase. Curr. Opin. Hematol. 7:53-58.

10. Hazen, S.L., Hsu, F.F., Duffin, K., and Heinecke, J.W. 1996. Molecular chlorine generated by the myeloperoxidase hydrogen peroxide chloride system of phagocytes converts low density lipoprotein cholesterol into a family of chlorinated sterols. J. Biol. Chem. 271:23080-23088.

11. Henderson, J.P., et al. 2001. Bromination of deoxycytidine by eosinophil peroxidase: a mechanism for mutagenesis by oxidative damage of nucleotide precursors. Proc. Natl. Acad. Sci. U. S. A. 98:1631-1636.

12. van Dalen, C.J., Winterbourn, C.C., Senthilmohan, R., and Kettle, A.J. 2000. Nitrite as a substrate and inhibitor of myeloperoxidase. Implications for nitration and hypochlorous acid production at sites of inflammation. J. Biol. Chem. 275:11638-11644.

13. Hazen, S.L., Hsu, F.F., d'Avignon, A., and Heinecke, J.W. 1998. Human neutrophils employ myeloperoxidase to convert $\alpha$-amino acids to a battery of reactive aldehydes: a pathway for aldehyde generation at sites of inflammation. Biochemistry. 37:6864-6873.

14. Esterbauer, H., Schaur, R.J., and Zollner, H. 1991. Chemistry and biochemistry of 4-hydroxynonenal, malonaldehyde and related aldehydes. Free Radic. Biol. Med. 11:81-128.

15. Lee, S.H., Oe, T., and Blair, I.A. 2002. 4,5-Epoxy-2(E)-decenal-induced formation of 1,N(6)-etheno-2'- deoxyadenosine and 1,N(2)-etheno-2'deoxyguanosine adducts. Chem. Res. Toxicol. 15:300-304.

16. Uchida, K. 2000. Role of reactive aldehyde in cardiovascular diseases. Free Radic. Biol. Med. 28:1685-1696.

17. Marnett, L.J., and Plastaras, J.P. 2001. Endogenous DNA damage and mutation. Trends Genet. 17:214-221.

18. Singer, B., and Essigmann, J.M. 1991. Site-specific mutagenesis: retrospective and prospective. Carcinogenesis. 12:949-955.

19. Wang, D., Kreutzer, D.A., and Essigmann, J.M. 1998. Mutagenicity and repair of oxidative DNA damage: insights from studies using defined lesions. Mutat. Res. 400:99-115.

20. Swenberg, J.A., et al. 2000. DNA adducts: effects of low exposure to ethylene oxide, vinyl chloride and butadiene. Mutat. Res. 464:77-86.

21. Chatgilialoglu, C., and O'Neill, P. 2001. Free radicals associated with DNA damage. Exp. Gerontol. 36:1459-1471.

22. Cadet, J., et al. 1999. Hydroxyl radicals and DNA base damage. Mutat. Res. 424:9-21.

23. Wagner, J.R., Hu, C.-C., and Ames, B.N. 1992. Endogenous oxidative damage of deoxycytidine in DNA. Proc. Natl. Acad. Sci. U. S. A. 89:3380-3384.

24. Tan, X., Grollman, A.P., and Shibutani, S. 1999. Comparison of the mutagenic properties of 8-oxo-7,8-dihydro-2'-deoxyadenosine and 8oxo-7,8-dihydro-2'-deoxyguanosine DNA lesions in mammalian cells. Carcinogenesis. 20:2287-2292.

25. Gentil, A., Le Page, F., Cadet, J., and Sarasin, A. 2000. Mutation spectra induced by replication of two vicinal oxidative DNA lesions in mammalian cells. Mutat. Res. 452:51-56.

26. Shibutani, S., Bodepudi, V., Johnson, F., and Grollman, A.P. 1993. Translesional synthesis on DNA templates containing 8-oxo-7,8-dihydrodeoxyadenosine. Biochemistry. 32:4615-4621.

27. Douki, T., Martini, R., Ravanat, J.L., Turesky, R.J., and Cadet, J. 1997. Measurement of 2,6-diamino-4-hydroxy-5-formamidopyrimidine and 8-oxo-7,8-dihydroguanine in isolated DNA exposed to gamma radiation in aqueous solution. Carcinogenesis. 18:2385-2391.

28. Hazra, T.K., Hill, J.W., Izumi, T., and Mitra, S. 2001. Multiple DNA glycosylases for repair of 8-oxoguanine and their potential in vivo functions. Prog. Nucleic Acid Res. Mol. Biol. 68:193-205.

29. Feig, D.I., Sowers, L.C., and Loeb, L.A. 1994. Reverse chemical mutagenesis: identification of the mutagenic lesions resulting from reactive oxygen species-mediated damage to DNA. Proc. Natl. Acad. Sci. U. S. A. 91:6609-6613.

30. McNulty, J.M., Jerkovic, B., Bolton, P.H., and Basu, A.K. 1998. Replication inhibition and miscoding properties of DNA templates containing a site-specific cis-thymine glycol or urea residue. Chem. Res. Toxicol. 11:666-673.

31. Basu, A.K., Loechler, E.L., Leadon, S.A., and Essigmann, J.M. 1989. Genetic effects of thymine glycol: site-specific mutagenesis and molecular modeling studies. Proc. Natl. Acad. Sci. U. S. A. 86:7677-7681.

32. Burney, S., Caulfield, J.L., Niles, J.C., Wishnok, J.S., and Tannenbaum, S.R. 1999. The chemistry of DNA damage from nitric oxide and peroxynitrite. Mutat. Res. 424:37-49.

33. Lee, J.M., Niles, J.C., Wishnok, J.S., and Tannenbaum, S.R. 2002. Perox- 
ynitrite reacts with 8-nitropurines to yield 8-oxopurines. Chem. Res. Toxicol. 15:7-14

34. Jaiswal, M., LaRusso, N.F., and Gores, G.J. 2001. Nitric oxide in gastrointestinal epithelial cell carcinogenesis: linking inflammation to oncogenesis. Am. J. Physiol. Gastrointest. Liver Physiol. 281:G626-G634.

35. Barbin, A. 2000. Etheno-adduct-forming chemicals: from mutagenicity testing to tumor mutation spectra. Mutat. Res. 462:55-69.

36. Blair, I.A. 2001. Lipid hydroperoxide-mediated DNA damage. Exp. Gerontol. 36:1473-1481.

37. Swenberg, J.A., et al. 1999. Formation and repair of DNA adducts in vinyl chloride- and vinyl fluoride-induced carcinogenesis. IARC Sci. Publ. 150:29-43.

38. Singer, B., and Hang, B. 1999. Mammalian enzymatic repair of etheno and para-benzoquinone exocyclic adducts derived from the carcinogens vinyl chloride and benzene. IARC Sci. Publ. 150:233-247.

39. Saparbaev, M., and Laval, J. 1999. Enzymology of the repair of etheno adducts in mammalian cells and in Escherichia coli. IARC Sci. Publ. 150:249-261.

40. Marnett, L.J. 1999. Chemistry and biology of DNA damage by malondialdehyde. IARC Sci. Publ. 150:17-27.

41. Mao, H., Schnetz-Boutaud, N.C., Weisenseel, J.P., Marnett, L.J., and Stone, M.P. 1999. Duplex DNA catalyzes the chemical rearrangement of a malondialdehyde deoxyguanosine adduct. Proc. Natl. Acad. Sci. U. S. A. 96:6615-6620

42. Fink, S.P., and Marnett, L.J. 2001. The relative contribution of adduct blockage and DNA repair on template utilization during replication of $1, N^{2}$-propanodeoxyguanosine and pyrimido. Mutat. Res. 485:209-218.

43. Hecht, S.S., McIntee, E.J., and Wang, M. 2001. New DNA adducts of crotonaldehyde and acetaldehyde. Toxicology. 166:31-36.

44. VanderVeen, L.A., et al. 2001. Evaluation of the mutagenic potential of the principal DNA adduct of acrolein. J. Biol. Chem. 276:9066-9070.

45. Yang, I.Y., et al. 2001. Responses to the major acrolein-derived deoxyguanosine adduct in Escherichia coli. J. Biol. Chem. 276:9071-9076.

46. Fink, S.P., Reddy, G.R., and Marnett, L.J. 1997. Mutagenicity in Escherichic coli of the major DNA adduct derived from the endogenous mutagen malondialdehyde. Proc. Natl. Acad. Sci. U. S. A. 94:8652-8657.

47. Bignami, M., O’Driscoll, M., Aquilina, G., and Karran, P. 2000. Unmasking a killer: DNA O(6)-methylguanine and the cytotoxicity of methylating agents. Mutat. Res. 462:71-82.

48. Jubb, A.M., Bell, S.M., and Quirke, P. 2001. Methylation and colorectal cancer. J. Pathol. 195:111-134.

49. Chen, H.J., Row, S.W., and Hong, C.L. 2002. Detection and quantification of 5-chlorocytosine in DNA by stable isotope dilution and gas chromatography/negative ion chemical ionization/mass spectrometry. Chem. Res. Toxicol. 15:262-268.

50. Masuda, M., et al. 2001. Chlorination of guanosine and other nucleosides by hypochlorous acid and myeloperoxidase of activated human neutrophils. Catalysis by nicotine and trimethylamine. J. Biol. Chem. 276:40486-40496.

51. Ji, C., Rouzer, C.A., Marnett, L.J., and Pietenpol, J.A. 1998. Induction of cell cycle arrest by the endogenous product of lipid peroxidation, malondialdehyde. Carcinogenesis. 19:1275-1283.

52. Dean, R.T., Fu, S., Stocker, R., and Davies, M.J. 1997. Biochemistry and pathology of radical-mediated protein oxidation. Biochem. J. 324:1-18.

53. Levine, R.L., and Stadtman, E.R. 2001. Oxidative modification of proteins during aging. Exp. Gerontol. 36:1495-1502.

54. Claiborne, A., et al. 1999. Protein-sulfenic acids: diverse roles for an unlikely player in enzyme catalysis and redox regulation. Biochemistry. 38:15407-15416.

55. Arner, E.S., and Holmgren, A. 2000. Physiological functions of thioredoxin and thioredoxin reductase. Eur. J. Biochem. 267:6102-6109.

56. Hess, D.T., Matsumoto, A., Nudelman, R., and Stamler, J.S. 2001. S-nitrosylation: spectrum and specificity. Nat. Cell Biol. 3:E46-E49.

57. Jaffrey, S.R., Erdjument-Bromage, H., Ferris, C.D., Tempst, P., and Snyder, S.H. 2001. Protein S-nitrosylation: a physiological signal for neuronal nitric oxide. Nat. Cell Biol. 3:193-197.

58. Gow, A.J., et al. 2002. Basal and stimulated protein S-nitrosylation in multiple cell types and tissues. J. Biol. Chem. 277:9637-9640.

59. Levine, R.L., Moskovitz, J., and Stadtman, E.R. 2000. Oxidation of methionine in proteins: roles in antioxidant defense and cellular regulation. IUBMB Life. 50:301-307.

60. Kryukov, G.V., Kumar, R.A., Koc, A., Sun, Z., and Gladyshev, V.N. 2002. Selenoprotein $\mathrm{R}$ is a zinc-containing stereo-specific methionine sulfoxide reductase. Proc. Natl. Acad. Sci. U. S. A. 99:4245-4250.

61. Moskovitz, J., et al. 2001. Methionine sulfoxide reductase (MsrA) is a regulator of antioxidant defense and lifespan in mammals. Proc. Natl. Acad. Sci. U. S. A. 98:12920-12925.

62. Ruan, H., et al. 2002. High-quality life extension by the enzyme peptide methionine sulfoxide reductase. Proc. Natl. Acad. Sci. U. S. A. 99:2748-2753.

63. Podrez, E.A., Abu-Soud, H.M., and Hazen, S.L. 2000. Myeloperoxidase-generated oxidants and atherosclerosis. Free Radic. Biol. Med. 28:1717-1725.
64. Frost, M.T., Halliwell, B., and Moore, K.P. 2000. Analysis of free and protein-bound nitrotyrosine in human plasma by a gas chromatography/mass spectrometry method that avoids nitration artifacts. Biochem. J. 345:453-458

65. Gaut, J.P., Byun, J., Tran, H.D., and Heinecke, J.W. 2002. Artifact-free quantification of free 3-chlorotyrosine, 3-bromotyrosine, and 3-nitrotyrosine in human plasma by electron capture-negative chemical ionization gas chromatography mass spectrometry and liquid chromatography-electrospray ionization tandem mass spectrometry. Anal. Biochem. 300:252-259.

66. Delatour, T., Richoz, J., Vuichoud, J., and Stadler, R.H. 2002. Artifactual nitration controlled measurement of protein-bound 3-nitro-L-tyrosine in biological fluids and tissues by isotope dilution liquid chromatography electrospray ionization tandem mass spectrometry. Chem. Res. Toxicol. 15:1209-1217.

67. Heinecke, J.W. 1998. Oxidants and antioxidants in the pathogenesis of atherosclerosis: implications for the oxidized low density lipoprotein hypothesis. Atherosclerosis. 141:1-15.

68. Pennathur, S., Jackson-Lewis, V., Przedborski, S., and Heinecke, J.W. 1999. Mass spectrometric quantification of 3-nitrotyrosine, ortho-tyrosine, and o,o'-dityrosine in brain tissue of 1-methyl-4-phenyl-1,2,3, 6-tetrahydropyridine-treated mice, a model of oxidative stress in Parkinson's disease. J. Biol. Chem. 274:34621-34628.

69. Sayre, L.M., Smith, M.A., and Perry, G. 2001. Chemistry and biochemistry of oxidative stress in neurodegenerative disease. Curr. Med. Chem. 8:721-738

70. Stamler, J.S., Lamas, S., and Fang, F.C. 2001. Nitrosylation: the prototypic redox-based signaling mechanism. Cell. 106:675-683.

71. Patel, R.P., et al. 2000. Cell signaling by reactive nitrogen and oxygen species in atherosclerosis. Free Radic. Biol. Med. 28:1780-1794.

72. Neely, M.D., Sidell, K.R., Graham, D.G., and Montine, T.J. 1999. The lipid peroxidation product 4-hydroxynonenal inhibits neurite outgrowth, disrupts neuronal microtubules, and modifies cellular tubulin. J. Neurochem. 72:2323-2333.

73. Wataya, T., et al. 2002. High molecular weight neurofilament proteins are physiological substrates of adduction by the lipid peroxidation product hydroxynonenal. J. Biol. Chem. 277:4644-4648.

74. MacMillan-Crow, L.A., Crow, J.P., Kerby, J.D., Beckman, J.S., and Thompson, J.A. 1996. Nitration and inactivation of manganese superoxide dismutase in chronic rejection of human renal allografts. Proc. Natl. Acad. Sci. U. S. A. 93:11853-11858

75. MacMillan-Crow, L.A., Crow, J.P., and Thompson, J.A. 1998. Peroxynitrite-mediated inactivation of manganese superoxide dismutase involves nitration and oxidation of critical tyrosine residues. Biochemistry. 37:1613-1622.

76. Yamakura, F., Taka, H., Fujimura, T., and Murayama, K. 1998. Inactivation of human manganese-superoxide dismutase by peroxynitrite is caused by exclusive nitration of tyrosine 34 to 3-nitrotyrosine. J. Biol. Chem. 273:14085-14089.

77. Ara, J., et al. 1998. Inactivation of tyrosine hydroxylase by nitration following exposure to peroxynitrite and 1-methyl-4-phenyl-1,2,3,6-tetrahydropyridine (MPTP). Proc. Natl. Acad. Sci. U. S. A. 95:7659-7663.

78. Blanchard-Fillion, B., et al. 2001. Nitration and inactivation of tyrosine hydroxylase by peroxynitrite. J. Biol. Chem. 276:46017-46023.

79. Kuhn, D.M., et al. 2002. Peroxynitrite-induced nitration of tyrosine hydroxylase: identification of tyrosines 423,428 , and 432 as sites of modification by matrix-assisted laser desorption ionization time-offlight mass spectrometry and tyrosine-scanning mutagenesis. J. Biol. Chem. 277:14336-14342.

80. Mannick, J.B., et al. 1999. Fas-induced caspase denitrosylation. Science. 284:651-654.

81. Rossig, L., et al. 1999. Nitric oxide inhibits caspase-3 by S-nitrosation in vivo. J. Biol. Chem. 274:6823-6826.

82. Zech, B., Wilm, M., van Eldik, R., and Brune, B. 1999. Mass spectrometric analysis of nitric oxide-modified caspase-3. J. Biol. Chem. 274:20931-20936.

83. Mannick, J.B., et al. 2001. S-nitrosylation of mitochondrial caspases. J. Cell Biol. 154:1111-1116.

84. Caselli, A., et al. 1998. The inactivation mechanism of low molecular weight phosphotyrosine-protein phosphatase by $\mathrm{H}_{2} \mathrm{O}_{2}$. J. Biol. Chem 273:32554-32560.

85. Barrett, W.C., et al. 1999. Roles of superoxide radical anion in signal transduction mediated by reversible regulation of protein-tyrosine phosphatase 1B. J. Biol. Chem. 274:34543-34546.

86. Barrett, W.C., et al. 1999. Regulation of PTP1B via glutathionylation of the active site cysteine 215. Biochemistry. 38:6699-6705.

87. Meng, T.C., Fukada, T., and Tonks, N.K. 2002. Reversible oxidation and inactivation of protein tyrosine phosphatases in vivo. Mol. Cell. 9:387-399.

88. Takakura, K., Beckman, J.S., MacMillan-Crow, L.A., and Crow, J.P. 1999. Rapid and irreversible inactivation of protein tyrosine phosphatases 
PTP1B, CD45, and LAR by peroxynitrite. Arch. Biochem. Biophys. 369:197-207.

89. Chiarugi, P., et al. 2001. Two vicinal cysteines confer a peculiar redox regulation to low molecular weight protein tyrosine phosphatase in response to platelet-derived growth factor receptor stimulation. J. Biol. Chem. 276:33478-33487.

90. Denu, J.M., and Tanner, K.G. 1998. Specific and reversible inactivation of protein tyrosine phosphatases by hydrogen peroxide: evidence for a sulfenic acid intermediate and implications for redox regulation. Biochemistry. 37:5633-5642.

91. Choi, H., et al. 2001. Structural basis of the redox switch in the OxyR transcription factor. Cell. 105:103-113.

92. Kim, S.O., et al. 2002. OxyR: a molecular code for redox-related signaling. Cell. 109:383-396.

93. Fratelli, M., et al. 2002. Identification by redox proteomics of glutathionylated proteins in oxidatively stressed human $\mathrm{T}$ lymphocytes. Proc. Natl. Acad. Sci. U. S. A. 99:3505-3510.

94. Aulak, K.S., et al. 2001. Proteomic method identifies proteins nitrated in vivo during inflammatory challenge. Proc. Natl. Acad. Sci. U. S. A. 98:12056-12061.

95. Mohr, S., Zech, B., Lapetina, E.G., and Brune, B. 1997. Inhibition of caspase- 3 by S-nitrosation and oxidation caused by nitric oxide. Biochem. Biophys. Res. Commun. 238:387-391.

96. Borutaite, V., and Brown, G.C. 2001. Caspases are reversibly inactivated by hydrogen peroxide. FEBS Lett. 500:114-118.

97. Caselli, A., et al. 1994. Nitric oxide causes inactivation of the low molecular weight phosphotyrosine protein phosphatase. J. Biol. Chem. 269:24878-24882.

98. Lee, S.R., Kwon, K.S., Kim, S.R., and Rhee, S.G. 1998. Reversible inactivation of protein-tyrosine phosphatase 1B in A431 cells stimulated with epidermal growth factor. J. Biol. Chem. 273:15366-15372.

99. Kamata, H., Shibukawa, Y., Oka, S.I., and Hirata, H. 2000. Epidermal growth factor receptor is modulated by redox through multiple mechanisms. Effects of reductants and $\mathrm{H}_{2} \mathrm{O}_{2}$. Eur. J. Biochem. 267:1933-1944.

100.Mahadev, K., Zilbering, A., Zhu, L., and Goldstein, B.J. 2001. Insulinstimulated hydrogen peroxide reversibly inhibits protein-tyrosine phosphatase $1 \mathrm{~b}$ in vivo and enhances the early insulin action cascade. J. Biol. Chem. 276:21938-21942.

101.Ji, C., Kozak, K.R., and Marnett, L.J. 2001. IkappaB kinase, a molecular target for inhibition by 4-hydroxy-2-nonenal. J. Biol. Chem. 276:18223-18228.

102.Korn, S.H., Wouters, E.F., Vos, N., and Janssen-Heininger, Y.M. 2001. Cytokine-induced activation of nuclear factor-kappa B is inhibited by hydrogen peroxide through oxidative inactivation of IkappaB kinase. J. Biol. Chem. 276:35693-35700.

103.Lander, H.M., Ogiste, J.S., Pearce, S.F., Levi, R., and Novogrodsky, A 1995. Nitric oxide-stimulated guanine nucleotide exchange on $\mathrm{p} 21$ ras. J. Biol. Chem. 270:7017-7020.

104.Lander, H.M., Ogiste, J.S., Teng, K.K., and Novogrodsky, A. 1995. p21ras as a common signaling target of reactive free radicals and cellular redox stress. J. Biol. Chem. 270:21195-21198.

105.Mirza, U.A., Chait, B.T., and Lander, H.M. 1995. Monitoring reactions of nitric oxide with peptides and proteins by electrospray ionizationmass spectrometry. J. Biol. Chem. 270:17185-17188.

106.Lander, H.M., et al. 1997. A molecular redox switch on p21(ras). Structural basis for the nitric oxide-p21(ras) interaction. J. Biol. Chem. 272:4323-4326.

107.Yun, H.Y., Gonzalez-Zulueta, M., Dawson, V.L., and Dawson, T.M. 1998 Nitric oxide mediates N-methyl-D-aspartate receptor-induced activation of p21ras. Proc. Natl. Acad. Sci.U. S. A. 95:5773-5778.

108. Molina y Vedia, L., et al. 1992. Nitric oxide-induced S-nitrosylation of glyceraldehyde-3-phosphate dehydrogenase inhibits enzymatic activity and increases endogenous ADP-ribosylation. J. Biol. Chem. 267:24929-24932.

109.Uchida, K., and Stadtman, E.R. 1993. Covalent attachment of 4-hydroxynonenal to glyceraldehyde-3-phosphate dehydrogenase. A possible involvement of intra- and intermolecular cross-linking reaction. J. Biol. Chem. 268:6388-6393.

110. Ravichandran, V., Seres, T., Moriguchi, T., Thomas, J.A., and Johnston, R.B., Jr. 1994. S-thiolation of glyceraldehyde-3-phosphate dehydrogenase induced by the phagocytosis-associated respiratory burst in blood monocytes. J. Biol. Chem. 269:25010-25015.

111.Mohr, S., Stamler, J.S., and Brune, B. 1996. Posttranslational modifica- tion of glyceraldehyde-3-phosphate dehydrogenase by S-nitrosylation and subsequent NADH attachment. J. Biol. Chem. 271:4209-4214.

112.Souza, J.M., and Radi, R. 1998. Glyceraldehyde-3-phosphate dehydrogenase inactivation by peroxynitrite. Arch. Biochem. Biophys. 360:187-194.

113.Mohr, S., Hallak, H., de Boitte, A., Lapetina, E.G., and Brune, B. 1999. Nitric oxide-induced S-glutathionylation and inactivation of glyceraldehyde-3-phosphate dehydrogenase. J. Biol. Chem. 274:9427-9430.

114. Rivera-Nieves, J., Thompson, W.C., Levine, R.L., and Moss, J. 1999. Thiols mediate superoxide-dependent NADH modification of glyceraldehyde-3-phosphate dehydrogenase. J. Biol. Chem. 274:19525-19531.

115.Buchczyk, D.P., Briviba, K., Hartl, F.U., and Sies, H. 2000. Responses to peroxynitrite in yeast: glyceraldehyde-3-phosphate dehydrogenase (GAPDH) as a sensitive intracellular target for nitration and enhancement of chaperone expression and ubiquitination. Biol. Chem. 381:121-126.

116. Banan, A., Fields, J.Z., Decker, H., Zhang, Y., and Keshavarzian, A. 2000 Nitric oxide and its metabolites mediate ethanol-induced microtubule disruption and intestinal barrier dysfunction. J. Pharmacol. Exp. Ther. 294:997-1008.

117. Manzoni, O., et al. 1992. Nitric oxide-induced blockade of NMDA receptors. Neuron. 8:653-662.

118.Lei, S.Z., et al. 1992. Effect of nitric oxide production on the redox modulatory site of the NMDA receptor-channel complex. Neuron. 8:1087-1099.

119.Lipton, S.A., et al. 1993. A redox-based mechanism for the neuroprotective and neurodestructive effects of nitric oxide and related nitroso-compounds. Nature. 364:626-632.

120. Choi, Y.B., et al. 2000. Molecular basis of NMDA receptor-coupled ion channel modulation by S-nitrosylation. Nat. Neurosci. 3:15-21.

121. Matthews, J.R., Wakasugi, N., Virelizier, J.L., Yodoi, J., and Hay, R.T. 1992. Thioredoxin regulates the DNA binding activity of NF-kappa B by reduction of a disulphide bond involving cysteine 62. Nucleic Acids Res. 20:3821-3830.

122. Hayashi, T., Ueno, Y., and Okamoto, T. 1993. Oxidoreductive regulation of nuclear factor kappa B. Involvement of a cellular reducing catalyst thioredoxin. J. Biol. Chem. 268:11380-11388.

123. Matthews, J.R., Botting, C.H., Panico, M., Morris, H.R., and Hay, R.T. 1996. Inhibition of NF-kappaB DNA binding by nitric oxide. Nucleic Acids Res. 24:2236-2242.

124.delaTorre, A., Schroeder, R.A., Punzalan, C., and Kuo, P.C. 1999. Endotoxin-mediated S-nitrosylation of p50 alters NF-kappa B-dependent gene transcription in ANA-1 murine macrophages. J. Immunol. 162:4101-4108.

125.Marshall, H.E., and Stamler, J.S. 2001. Inhibition of NF-kappa B by S-nitrosylation. Biochemistry. 40:1688-1693.

126. Pineda-Molina, E., et al. 2001. Glutathionylation of the p50 subunit of NF-kappaB: a mechanism for redox-induced inhibition of DNA binding. Biochemistry. 40:14134-14142.

127. Abate, C., Patel, L., Rauscher, F.J., 3rd, and Curran, T. 1990. Redox regulation of fos and jun DNA-binding activity in vitro. Science. 249:1157-1161.

128. Nikitovic, D., Holmgren, A., and Spyrou, G. 1998. Inhibition of AP-1 DNA binding by nitric oxide involving conserved cysteine residues in Jun and Fos. Biochem. Biophys. Res. Commun. 242:109-112.

129. Klatt, P., et al. 1999. Redox regulation of c-Jun DNA binding by reversible S-glutathiolation. FASEBJ. 13:1481-1490.

130. Klatt, P., Molina, E.P., and Lamas, S. 1999. Nitric oxide inhibits c-Jun DNA binding by specifically targeted S-glutathionylation. J. Biol. Chem. 274:15857-15864.

131.Storz, G., Tartaglia, L.A., and Ames, B.N. 1990. Transcriptional regulator of oxidative stress-inducible genes: direct activation by oxidation. Science. 248:189-194.

132. Kullik, I., Toledano, M.B., Tartaglia, L.A., and Storz, G. 1995. Mutational analysis of the redox-sensitive transcriptional regulator OxyR: regions important for oxidation and transcriptional activation. J. Bacteriol. 177:1275-1284.

133. Hausladen, A., Privalle, C.T., Keng, T., DeAngelo, J., and Stamler, J.S. 1996. Nitrosative stress: activation of the transcription factor OxyR. Cell. 86:719-729.

134.Zheng, M., Aslund, F., and Storz, G. 1998. Activation of the OxyR transcription factor by reversible disulfide bond formation. Science. 279:1718-1721 